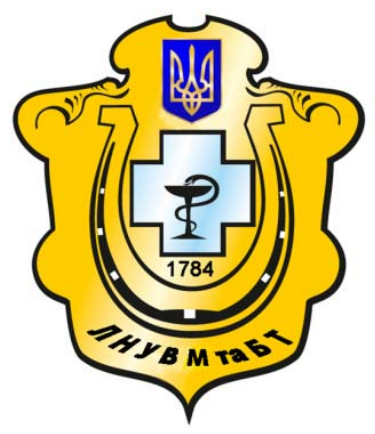

Науковий вісник Львівського національного університету ветеринарної медицини та біотехнологій імені С.3. Гжицького

Scientific Messenger of Lviv National University of Veterinary Medicine and Biotechnologies named after S.Z. Gzhytskyj

doi:10.15421/nvlvet6611

ISSN 2413-5550 print

ISSN $2518-1327$ online

$\underline{\text { http://nvlvet.com.ua/ }}$

УДК 636.598

\title{
Вплив фумонізинотоксикозу на морфологічні та біохімічні показники крові щурів
}

\author{
3.А. Гута \\ bvh@ukr.net
}

Львівський національний університет ветеринарної медицини та біотехнологій імені С.3. Гжицького, вул. Пекарська, 50, м. Львів, 79010, Украӥна

У статті вивчено вплив фумонізинів на морфологічні та біохімічні показники крові щурів. В експерименті використали 20 шурів масою тіла 165-170 г. Було сформовано 2 групи: I - група тварин служила контролем, у дослідній II групі тварин відтворювали хронічний фумонізинотоксикоз. Щурам щзоденно вводили внутрішньо-илунково 90 мг фумонізину на одну тварину.

Встановлено, щзо після введення фумонізину щурам, мікотоксини чинять негативний вплив на морфологічні показники крові щурів. Встановлено вірогідне зростання кількості лейкоцитів до 18,9 Г/л, числа еозинофілів до 6,7\%, сегментоядерних нейтрофілів до 30,7\%, а також зниження кількості лімфоцитів та моноцитів до 56,0 і 0,7\%. При аналізі лейкоцитарноі формули відмічали тенденцію до зсуву ядра вліво.

Реакиії, які виникають на тлі вищезгаданого токсикозу, зумовлені селективним тропізмом на різні тканини організму, внаслідок чого виникають нейро-, гепато- та нефротоксичні реакиії. Діагностувати такі зміни можна після всебічного вивчення з урахуванням біохімічних змін. При дослідженні біохімічних показників крові щурів за розвитку хронічного фуманізинотоксикозу встановлено зниження рівня загального протеїну, щчо вказує на розвиток порушень обміну білків в організмі щурів і протеїнсинтезувальної функиії печінки. Також встановлено, щзо за умов фуманізинотоксикозу у щурів активність аланін-амінотрансферази та аспартат-амінотрансферази у їх крові упродовж усього досліду зростала. Це пояснюється підвищеною проникністю клітин під впливом фумонізину, щзо впливав безпосередньо на мембрани, правдоподібно, порушуючи їх структурні складові. Концентрачія креатиніну та сечовини у крові дослідної групи щурів, яким згодовували фуманізин, перевищувала фізіологічні величини, що було клінічною ознакою розвитку запального процесу в організмі щурів.

На 14 добу фагоцитарна активність нейтрофілів та фагоцитарний індекс у крові шурів уражених фуманізинами, знижувався, щзо вказувало на наявність змін в імунній системі тварин.

ключові слова: фармакологія, токсикологія, мікотоксини, фумонізини, щурі, кров.

\section{Влияние фумонизинотоксикоза на морфологические и биохимические показатели крови крыс}

\author{
3.А. Гута \\ bvh@ukr.net
}

\begin{abstract}
Львовский национальный университет ветеринарной медицины и биотехнологий имени С.3. Гжицкого, ул. Пекарская, 50, г. Львов, 79010, Украина
\end{abstract}

В статье изучено влияние фумонизинов на морфологические и биохимические показатели крови крыс. В эксперименте использовали 20 крыс массой тела 165-170 г. Было сформировано 2 группы: I - группа животных служила контролем, 6 исследовательской II группе животных воспроизводили хронический фумонизинотоксикоз. Крысам ежедневно вводили внутри-желудочно 90 мг фумонизинов на одно животное.

Citation:

Guta, Z. (2016). The influence of fumonisin toxicity on morphological and biochemical blood parameters in rats. Scientific Messenger LNUVMBT named after S.Z. Gzhytskyj, 18, 2(66), 48-51. 
Установлено, что после введения фумонизинов крысам, микотоксины оказывают негативное влияние на морфологические показатели крови крыс. Установлено достоверное увеличение количества лейкоцитов до 18,9 г/л, числа эозинофилов до 6,7\%, сегментоядерных нейтрофилов до 30,7\%, а также снижение количества лимфоцитов и моноцитов до 56,0 и 0,7\%. При анализе лейкоцитарной формуль отмечали тенденцию к смещению ядра влево.

Реакции, которые возникают на фоне вышеупомянутого токсикоза, обусловленные селективным тропизмом на различные ткани организма, в результате чего возникают нейро-, гепато- и нефротоксические реакиии. Диагностировать такие изменения можно после всестороннего изучения с учетом биохимических изменений. При исследовании биохимических показателей крови крыс при развитии хронического фуманизинотоксикоза установлено снижение уровня общего белка, что указывает на развитие нарушений обмена белков в организме крыс и белоксинтезирующей функции печени. Также установлено, что в условиях фуманизинотоксикоза у крыс активность аланин-аминотрансферазы и аспартатаминотрансферазы в их крови на протяжении всего опыта росло. Это объясняется повышенной проницаемостью клеток под влиянием фумонизинов, влияющим непосредственно на мембраны, вероятно, нарушая их структурнье составляющие. Концентрачия креатинина и мочевины в крови опытной группь крыс, которым скармливали фуманизин превьлиала физиологические величины, было клиническим признаком развития воспалительного процесса в организме крыс.

На 14 сутки фагоцитарная активность нейтрофилов и фагоцитарный индекс в крови крыс пораженных фуманизинамы, снижался, что указывало на наличие изменений в иммунной системе животных.

Ключевые слова: фармакология, токсикология, микотоксины, фумонизинов, крысы, кровь.

\title{
The influence of fumonisin toxicity on morphological and biochemical blood parameters in rats
}

\author{
Z. Guta \\ bvh@ukr.net

\begin{abstract}
Lviv national university of veterinary medicine and biotechnologies named after S. Gzhytskyj Pekarska Str., 50, Lviv, 79010, Ukraine
\end{abstract}

The article deals with the influence of fumonisins on morphological and biochemical indices of rats blood. 20 rats weighing 165$170 \mathrm{~g}$ were used in the experiment. It was formed two groups: first group of animals - served as a control, in the second experimental group - chronic fumonisin toxicosis was reproduced. Rats were daily injected with intra- gastro intestinal 90 mg of fumonisin per one animal.

It was established that after the introduction of fumonisin to rats, mycotoxins have a negative impact on the morphological indices of rats blood. It wass found a probable increase in the number of leukocytes to $18.9 \mathrm{~g} / \mathrm{l}$, the number of eosinophils to $6.7 \%$ segmented neutrophils to $30.7 \%$, and also the decrease in the number of lymphocytes and monocytees to 56.0 and $0.7 \%$. In the analysis of leukocyte formula we have noted the tendency to displacement the nucleus left.

Reactions that occur on the background of the above mentioned toxicity,caused by selective tropism for various tissues of the body; as a result there are nefro-, hepato- and nephrotoxic reactions.

To diagnose these changes is possible after a comprehensive study on the basis of biochemical changes. At research of biochemical parameters in rats blood by the development of chronic fumonisin toxicosis it was set the reduction of the level of total protein; indicating the development of violations of proteins exchange in rats organism and protein synthesized liver function.

Also it was found that under the conditions of fumonisin toxicosis in rats, alanine -aminotransferase activity and aspartateaminotransferase in their blood throughout the experiment was increased.This is explained by increased permeability of cells under the influence of fumonisin that influenced directly on the membrane, probably, disrupting their structural components. The concentration of creatinine and urea in the blood of experimental rats which were fed with fumonisin, exceeded the physiological values that were clinical sign of the development of inflammation in rats organism.

On the $14^{\text {th }}$ day the phagocytic activity of neutrophils and phagocytic index of rat blood affected by fumonisin was reduced, indicating the availability of such changes in the immune system of animals.

Key words: pharmacology, toxicology, mycotoxins, fumonisin, rats, blood.

\section{Вступ}

Фумонізини - це група мікотоксинів, які володіють нефротоксичною дією, що викликає енцефаломаляцію і зміни в лейкоцитарному складу крові. Фумонізини руйнують клітинні мембрани, що в першу чергу призводить до ураження печінки і нирок сільськогосподарських тварин (Smirnov et al., 2000; Grisler and Zasekin, 2008; Duhnyc'kyj et al., 2010; Ivanov et al., 2012).

Вважають, що основним у механізмі токсичної дії фумонізинів $є$ блокування процесу синтезу ліпідів у біологічних мембранах клітин. Вони є специфічними інгібіторами церамідсинтетази - основного ензиму в ланцюгу утворення церамідів і складніших сфінголіпідів - основної групи ліпідів, що входять до складу клітинної мембрани. Токсичність фумонізинів заснована на структурній подібності з сфінгоосновами, сфінгозином і сфінганіном (Munkvold et al., 1999; Kim et al., 2002). Сфінголіпіди дуже важливі для мембран, ліпопротеїнової структури, а також для клітинної регуляції і комунікації. Фумонізини, впливають на синтез ліпідів через нервові клітини. Вони також діють на печінку, викликають жовтяницю і жовто-оранжеве забарвлення, що виявляється на патологанатомічному розтині. Наявність можна легко визначити за співвідношенням сфінганіну до сфінгозину в печінці, підшлунковій залозі і наднирникових залозах (Kim et al., 2002; Duhnyc'kyj et al., 2010). Це використовують, як біомаркер для підтвердження отруєння фумонізинів. 
Отже, актуальним у науковому аспекті $є$ дослідження механізмів токсичної дії фумонізинів в організмі тварин.

Метою наших досліджень було вивчити вплив фумонізинотоксикозу на морфологічні та біохімічні показники крові щурів.

\section{Матеріал і методи досліджень}

Дослідження проводили в умовах віварію ДНДКІ ветеринарних препаратів та кормових добавок (м. Львів). В експерименті використано 20 щурів масою тіла 165-170 г. Було сформовано 2 групи. I група тварин служила контрольною, у дослідній II групі тварин відтворювали хронічний фумонізинотоксикоз. Щурам щоденно вводили внутрішньошлунково 90 мг фумонізину на одну тварину.

На 14 добу досліду щурів зважували та відбирали кров для гематологічних, імунологічних та біохімічних досліджень, шляхом декапітації, під легким ефірним наркозом, дотримуючись положення Свропейської конвенції із захисту хребетних тварин, які використовуються в експериментах та інших наукових цілях (Страсбург, 1986).

У стабілізованій крові досліджували морфологічні показники: кількість еритроцитів, лейкоцитів, виводили лейкограму, рівень гематокриту, вміст гемоглобіну в крові визначали нефелометрично гемоглобінціанідним методом. Загальну кількість лейкоцитів та еритроцитів у крові досліджували на сітці Горяєва лічильної камери, лейкограму виводили на основі мікроскопії мазків крові із диференціальним підрахунком різних форм лейкоцитів. Для оцінки функціональної активності нейтрофільних гранулоцитів використали показники, які визначали традиційними методами: фагоцитарну активність, фагоцитарний індекс (інтенсивність фагоцитозу). Оцінку фагоцитозу in vitro проводили через 30 хв. після початку інкубації з культурою мікроорганізмів E. coli. Про інтенсивність фагоцитозу судили за показником фагоцитарного індексу.

Біохімічні показники: загальний вміст білка, креатиніну, сечовини, АсАТ, АлАТ, лужної фосфатази (ЛФ), ГГТ, амілази в сироватці крові визначали за допомогою напівавтоматичного аналізатора (HumaLyzer 3000) (Vlizlo et al., 2012).

Статистичне опрацювання отриманих результатів експериментальних досліджень проводили за програмою статистичного пакету аналізу даних у Microsoft Exel-97. Для визначення вірогідності відмінностей між середніми величинами використовували $\mathrm{t}$ критерій Стьюдента.

\section{Результати та їх обговорення}

Результати гематологічних досліджень у щурів за розвитку фумонізинотоксикозу наведені у табл. 1. Після аналізу отриманих результатів гематологічних досліджень на 14 добу у щурів дослідної групи виявили вірогідне зростання кількості лейкоцитів до 18,9 Г/л, числа еозинофілів до 6,7\%, сегментоядерних нейтрофілів до $30,7 \%$, а також зниження кількості лімфоцитів та моноцитів до 56,0 і 0,7\% порівняно до контрольної групи. Після аналізу лейкограми відзначали тенденцію до зсуву ядра вліво. Ці результати вказували на наявність запальних процесів і зниження імунного захисту організму тварин у цілому.

Таблиия 1

Морфологічні показники крові щурів за умов фумонізинотоксикозу на 14 добу досліду, $(\mathbf{M} \pm \mathbf{m}, \mathbf{n}=\mathbf{1 0})$

\begin{tabular}{|c|c|c|}
\hline \multirow{2}{*}{ Показники } & \multicolumn{2}{|c|}{ Групи тварин } \\
\cline { 2 - 3 } & І контроль & II токсин \\
\hline Гемоглобін, г/л & $131,2 \pm 10,9$ & $115,4 \pm 5,0$ \\
\hline Еритроцити, Т/л & $7,7 \pm 0,1$ & $9,4 \pm 0,6$ \\
\hline Гематокрит, \% & $31,6 \pm 1,2$ & $28,0 \pm 0,6$ \\
\hline Лейкоцити, Г/л & $8,0 \pm 1,7$ & $18,9 \pm 1,5^{* *}$ \\
\hline Лімфоцити, \% & $68,0 \pm 1,1$ & $56,0 \pm 2,0$ \\
\hline Паличкоядерні, \% & - & $2,0 \pm 0,0$ \\
\hline Сегментоядерні,\% & $21,5 \pm 7,2$ & $30,7 \pm 2,4$ \\
\hline Моноцити, \% & $1,3 \pm 0,7$ & $0,7 \pm 0,7$ \\
\hline Еозинофіли, \% & $2,0 \pm 1,1$ & $6,7 \pm 0,7^{*}$ \\
\hline
\end{tabular}

Реакції, які виникають на тлі вищезгаданого токсикозу, зумовлені селективним тропізмом на різні тканини організму, внаслідок чого виникають нейро-, гепато- та нефротоксичні реакції. Діагностувати такі зміни можна після всебічного вивчення з урахуванням біохімічних змін. Результати згаданих вище змін проведених досліджень крові щурів наведені у табл. 2.

Таблиия 2

Біохімічні показники сироватки крові щурів за умов фумонізинотоксикозу на 14 добу досліду $(\mathbf{M} \pm \mathbf{m}, \mathbf{n}=\mathbf{1 0})$

\begin{tabular}{|c|c|c|}
\hline \multirow{2}{*}{ Показники } & \multicolumn{2}{|c|}{ Групи тварин } \\
\cline { 2 - 3 } & І контроль & II токсин \\
\hline Протеїн загальний, г/л & $79,6 \pm 1,4$ & $63,3 \pm 1,5^{*}$ \\
\hline АлАт, Од/л & $74,03 \pm 4,2$ & $66,2 \pm 6,5$ \\
\hline АсАт, Од/л & $226,9 \pm 24,8$ & $439,4 \pm 31,2^{*}$ \\
\hline ЛФ, Од/л & $290,8 \pm 21,9$ & $275,1 \pm 19,5$ \\
\hline ГГТ, Од/л & $2,0 \pm 1,0$ & $3,0 \pm 0,2 *$ \\
\hline ФАН, \% & $26,6 \pm 1,1$ & $22,3 \pm 4,3$ \\
\hline ФІ, м.т./нейтр. & $12,6 \pm 1,1$ & $9,9 \pm 1,0$ \\
\hline Сечовина, Ммоль/л & $5,6 \pm 0,6$ & $7,1 \pm 0,5$ \\
\hline Креатинін, мкмоль/л & $93,9 \pm 2,6$ & $111,4 \pm 0,8^{*}$ \\
\hline Амілаза, Од/л & $1715 \pm 80,7$ & $2038 \pm 44,8$ \\
\hline
\end{tabular}

Встановлено вищу активність амінотрансфераз у щурів дослідної групи, де порівняно з контрольною групою активність АсАТ зросла майже у 2 рази. Дані зміни активності амінотрансфераз пояснюється підвищеною проникністю клітин під впливом фумонізину, що впливав безпосередньо на мембрани, правдоподібно, порушуючи їх структурні складові.

Концентрація креатиніну та сечовини у тварин дослідної групи перевищувала фізіологічні величини, що було клінічною ознакою розвитку запального процесу в організмі щурів на тлі розвитку токсикозу.

Зниження вмісту загального протеїну за фумонізинотоксикозу вказує на розвиток порушень обміну білків в організмі тварин. 
Також згідно даних літератури, відомо, що фумонізини володіють гепато- та нефротоксичною дією, негативно впливають на центральну нервову систему, несуть канцерогенний та імуносупресивний ефекти (Fodor et al., 2006; Wit et al., 2010). Варто й врахувати те, що у природних умовах мікотоксикози частіше перебігають у вигляді асоційованих форм, коли на організм одночасно діє декілька мікотоксинів. Окрім цього, унаслідок негативного впливу вторинних метаболітів плісеневих грибів на органи імунної системи зростає ймовірність ураження макроорганізму патогенними та умовнопатогенними мікроорганізмами. У таких випадках на фоні мікотокикозу, нерідко, розвиваються інфекційні захворювання різноманітного генезy (Dankovych and Andrijchuk, 2013).

\section{Висновки}

Розвиток фумонізинотоксикозу у щурів призводить до зміни морфологічного та біохімічного складу крові. Встановлено вірогідне зростання кількості лейкоцитів, числа еозинофілів та сегментоядерних нейтрофілів, а також зниження кількості лімфоцитів та моноцитів. Після аналізу лейкограми відзначали тенденцію до зсуву ядра вліво.

При дослідженні біохімічних показників крові, встановлено підвищену активність амінотрансфераз. Очевидно, в цьому процесі відбувалися і функціональні зміни в печінці досліджуваних тварин. Зокрема, підвищення активності ензиму АсАТ вказує на порушення цілісності клітин печінки. Особливо це підтверджується у тварин дослідної групи, на що вказує підвищення активності ГГТ, яке відображає стан печінки та гепатобіарного тракту.

Отримані результати досліджень будуть застосовані у подальшому вивчені патогенезу фумонізинотоксикозу у крові сільськогосподарських тварин та птиці та для розробки ефективного препарату для лікування тварин за фумонізинотоксикозу. Найпрактичніші методи дезінтоксикації мікотоксинів у тваринництві та птахівництві засновані на використанні 3 ушкодженим кормом препаратів-сорбентів (Косјumbas et al., 2011). Останні знижують біологічну активність мікотоксинів, зменшують всмоктування токсинів у травному тракті тварин, захищають продукцію від забруднення (Kocjumbas et al., 2009).

\section{Бібліографічні посилання}

Vlizlo, V.V., Fedoruk, R.S., Ratych, I.B. (2012). Laboratorni metody doslidzhen' u biologii', tvarynnyctvi ta veterynarnij medycyni: dovidnyk. L'viv: Spolom (in Ukrainian)

Duhnyc'kyj, V.B., Hmel'nyc'kyj, G.O., Bojko, G.V., Ishhenko, V.D. (2010). Veterynarna mikotoksykologija: navchal'nyj posibnyk. K. (in Ukrainian)

Ivanov, A.V., Fisinin, V.I., Tremasov, M.Ja., Papunidi, K.H. (2012). Mikotoksiny. M.: FGBNU «Rosinformagroteh» (in Russian).

Grisler, K., Zasekin, M. (2008). Fumoniziny. Real'naja opasnost' dlja s. -h. zhivotnyh i sposoby bor'by s nej. Efektivni kormi ta godivlja. 1(25), 39-42 (in Russian).

Smirnov, V.V., Zajchenko, A.M., Ribezhnel, G. (2000). Mikotoksiny: fundamental'nye j prikladnye aspekty. Sovremennye problemy toksikologii. 1, 5-12 (in Russian).

Munkvold, G.P., Hellmich, R.L., Rice, L.G. (1999). Comparison of fumonisin concentrations in kernels of transgenic $\mathrm{Bt}$ maize hybrids and nontransgenic hybrids. Plant Dis. 83(2), 130-138

Kim, E.K., Shon, D.H., Chung, S.H., Kim, Y.B. (2002). Survey for fumonisin B1 in Korean corn-based food products. Food Additives Contaminants. 19(5), 459464.

Fodor, J., Meyer, K., Riedlberger, M. (2006). Distribution and elimination of fumonisin analogues in weaned piglets after oral administration of Fusarium verticillioides fungal culture. Food Additives \& Contaminants. 23(5), 492-501.

Wit, M., Waskiewicz, A., Golinski, P. (2010). Occurrence of fumonisin FB1 in kernels and rachis of maize cobs infected by Fusarium verticillioides. Progress in plant protection. Inst. of plant protection. Poznan. 18321836.

Dankovych, R.S., Andrijchuk, A.V. (2013). Patomorfologichni zminy $u$ vnutrishnih organah svynej za asocijovanogo mikotoksykozu, uskladnenogo psevdomonozom. Naukovyj visnyk L'vivs'kogo nacional'nogo universytetu veterynarnoi' medycyny ta biotehnologij im. G'zhyc'kogo. 15, 1(1), 302-307.

Kocjumbas, I.Ja., Obrazhej, A.F., Brezvyn, O.M., Vasjanovych, O.M. (2011). Vykorystannja ta ocinka kormovyh dobavok, sorbentiv pry mikotoksykozah: metodychni rekomendacii'. L'viv (in Ukrainian).

Kocjumbas, I.Ja., Brezvyn, O.M., Kushnir, R.O. (2009). Vykorystannja sorbentiv u praktyci veterynarnoi' medecyny. Naukovo-tehnichnyj bjuleten' Instytutu biologii' tvaryn i DNDKI vetpreparativ ta korm. dobav. 10(4), 584-588 (in Ukrainian).

Стаття надійшла до редакції 1.09.2016 